\title{
Kernstappe vir kwaliteitbestuur in die vertaalbedryf en in akademiese vertaalkantore ${ }^{1}$
}

\author{
Alta van Rensburg \\ Departement Afrikaans en Nederlands, Universiteit Stellenbosch, Suid-Afrika \\ E-pos: avrens@sun.ac.za
}

\section{Opsomming}

Taaldienste soos vertaling, redigering en tolking is van kardinale belang in 'n meertalige samelewing en aan 'n hoëronderriginstelling waar die taaldiversiteit van sy personeel en studente erken word. Die vertaling van eksamenvraestelle is 'n voorbeeld van hoërisikovertaling, aangesien 'n onakkurate vertaling studentesukses negatief kan beïnvloed. Foute wat in die vertaling van toetse begaan is (Drugan 2013; Van Dyk, Van Rensburg en Marais 2011) beklemtoon die noodsaaklikheid van kwaliteitbestuur in vertaling. Kwaliteit is egter ' $n$ relatiewe begrip en word op verskillende maniere in die vertaalteorie en in die vertaalbedryf geïnterpreteer. In die vertaalteorie word kwaliteit hoofsaaklik gelykgestel met die assessering van die vertaalproduk, terwyl die fokus in die vertaalbedryf eerder op die produksieproses van die vertaling val om voldoende kwaliteit te verseker (Chesterman en Wagner 2002). Ek het vyf kwaliteitstandaarde vir die vertaalbedryf ontleed en die kernstappe in die kwaliteitbestuurproses in hierdie artikel beskryf. Daardie kwaliteitstandaarde is die Europese EN 15038 Translation services - Service requirements (2006), die Kanadese CAN/CGSB 131.10 Translation services (2008), die internasionale ISO/TS 11669 Translation projects - General guidance (2012), die Amerikaanse ASTM F2575 Standard guide for quality assurance in translation (2014), en die internasionale ISO 17100 Translation services Requirements for translation services (2015). Verskille en ooreenkomste tussen die siening van kwaliteit in die vertaalbedryf en in die vertaalteorie word uitgewys. In hierdie artikel word die gevolgtrekking gemaak dat akademiese vertaalkantore as gevolg van groot finansiële druk nie al die kernstappe vir kwaliteitbestuur kan toepas nie: Hulle word genoop om die risiko's en beskikbare hulpbronne teen mekaar op te weeg om die verlangde kwaliteit met slegs die nodige hulpbronne te lewer.

Trefwoorde: funksionalistiese vertaalbenaderings, hoër onderrig, kwaliteitstandaarde, kwaliteitversekering, produksieproses

1 Hierdie artikel is gebaseer op my PhD-studie oor revisie as een aspek van kwaliteitbestuur in 'n akademiese vertaalkantoor, onder die leiding van prof Ilse Feinauer. 


\title{
Key quality management steps in the translation industry and academic translation offices
}

\begin{abstract}
Language services such as translation, editing and interpreting are crucial in a multilingual society and at a higher education institution that acknowledges its staff and students' language diversity. The translation of examination papers is an example of high-stakes translation, as an inaccurate translation may negatively affect student success. Errors made in the translation of test papers (Drugan 2013; Van Dyk, Van Rensburg and Marais 2011) point to the necessity of quality management of translations. Yet quality is a relative concept with varied interpretations in translation theory and the translation industry. In translation theory, quality is primarily equated with the assessment of the translated product, whereas the translation industry places more emphasis on the process of producing the translation in order to ensure sufficient quality (Chesterman and Wagner 2002). This contribution describes the key steps in the quality management process based on my analysis of the five quality standards for the translation industry. Those quality standards are the European EN 15038 Translation services - Service requirements (2006), the Canadian CAN/CGSB 131.10 Translation services (2008), the international ISO/TS 11669 Translation projects - General guidance (2012), the American ASTM F2575 Standard guide for quality assurance in translation (2014), and the international ISO 17100 Translation services - Requirements for translation services (2015). Similarities and dissimilarities between the interpretation of quality in the translation industry and translation theory are identified. The article concludes that, due to substantial financial pressure, academic translation offices are unable to implement all the key quality management steps: Instead, they are compelled to weigh up the risks and available resources in order to deliver the desired quality with the minimum resources required.
\end{abstract}

Keywords: functionalist translation approaches, higher education, production process, quality assurance, quality standards

\section{Inleiding}

In 'n akademiese konteks waar meertaligheid noodsaaklik is om soveel moontlik studente toegang tot die Universiteit Stellenbosch (US) te bied, is vertaling 'n belangrike meganisme ter uitvoering van die US se Taalbeleid (US 2016). Studiemateriaal soos moduleraamwerke en MS PowerPoint-skyfies word in Afrikaans en Engels beskikbaar gestel en toetse en eksamenvraestelle word vertaal, aangesien studente kan kies in watter taal hulle die toets of eksamen wil aflê.

Die vertaling van eksamenvraestelle is 'n voorbeeld van hoërisikovertaling (high-stakes translation), aangesien ' $n$ onakkurate vertaling studentesukses negatief kan beïnvloed. Van Dyk, Van Rensburg en Marais (2011) beskryf die vertaling van 'n akademiesegeletterdheidstoets vir eerstejaarstudente uit Afrikaans in Engels: Hulle bevind dat die enigste vertaalfout in die vraestel veroorsaak het dat die Engelse studente die vraag verkeerd verstaan het. Gevolglik het slegs 24,5\% van die Engelse studente teenoor 48,6\% van die Afrikaanse studente die vraag korrek beantwoord. Dit is dus van kardinale belang dat die kwaliteit van veral sulke hoërisikovertalings op verskeie maniere verseker word. 
'Kwaliteit' is egter 'n relatiewe begrip, en verskillende rolspelers interpreteer kwaliteit in vertaling op verskillende maniere. In die vertaalteorie word daar hoofsaaklik op die gehalte van die vertaalproduk en die assessering daarvan gefokus. 'n Voorbeeld hiervan is in die Routledge Encyclopedia of Translation Studies (Baker en Saldanha 2009), wat onder die meer algemene opskrif Quality slegs verskillende assesseringsmodelle beskryf, soos dié van Reiss (1971/2000) en House (1997, 2007), wat in die konteks van vertaalopleiding geskep is. Teenoor hierdie akademiese assesseringsmodelle word daar in die vertaalbedryf gefokus op die kwaliteit van die vertaaldiens wat gelewer word, en watter produksieproses of werkvloei in die vertaalkantoor gevolg moet word om 'n diens van hoë gehalte aan kliënte te verseker. Die assessering van die vertaalproduk is dus slegs een deel van 'n breër siening van kwaliteit in vertaling waarvolgens gestandaardiseerde riglyne gevolg word om te verseker dat prosesse, dienste en produkte geskik is vir hulle doel: Dít is die sogenaamde "fit for purpose"-beginsel (ISO s.j.(a)). Hierdie gestandaardiseerde riglyne word uiteengesit in dokumente wat kwaliteitstandaarde genoem word, soos die standaarde wat in afdeling 2 bespreek word. 'n Prosesbenadering word gevolg: Die aksies om hoë gehalte in produkte of dienste te verseker, word as onderling verbonde prosesse binne 'n koherente kwaliteitbeheerstelsel bestuur ten einde konsekwente en voorspelbare resultate te verkry.

In die vertaalteorie word die 'vertaalproses' hoofsaaklik gesien as die kognitiewe proses wat vertalers in die skep van die vertaling volg (kyk bv. Göpferich, Jakobsen en Mees 2008; Schwieter en Ferreira 2017; Shreve en Angelone 2010). Aspekte wat nagevors word, sluit in hoe ervare vertalers se proses van onervare vertalers s'n verskil, watter strategieë vertalers volg om vertaalprobleme op te los, of daar verskille in die kognitiewe proses is wanneer vertalers in hulle eerste teenoor hulle tweede taal vertaal, en hoe vertaalvermoë ontwikkel (Englund Dimitrova 2010:406-411).

Daarteenoor word die breër siening van die produksieproses waarby verskillende rolspelers betrokke is, in die vertaalteorie beskryf deur funksionalistiese benaderings tot vertaling soos Vermeer $(1978,1996)$ se skoposteorie (ook Reiss en Vermeer 1984, 1991) met Nord (1991, 2005) se byvoeging van die lojaliteitsbeginsel, en Holz-Mänttäri (1984) se handelingsteorie vir vertaling (translatorial action). Volgens funksionalistiese vertaalbenaderings is vertaling 'n doelbewuste kommunikatiewe handeling tussen die brontaal- en doeltaalkultuur (Schäffner 2009:115). Vertalers word as kundiges in interkulturele kommunikasie gesien: Hulle werk saam met die kliënt en stel 'n vertaalopdrag op waarin aspekte soos die spesifieke doel van die vertaling in die doeltaalkultuur en die sosio-kulturele konteks van die doeltekslesers beskryf word. ${ }^{2}$ Die vertaling word aan die hand van hierdie inligting geskep en die gehalte daarvan word beoordeel volgens die mate waarin die spesifikasies in die vertaalopdrag nagekom is. Hiermee het die fokus in die vertaalteorie verskuif vanaf die reproduksie van 'n bronteks na die skep van 'n doelteks wat 'n spesifieke doel in daardie doeltaalkultuur moet vervul' ${ }^{3}$ en die verskeie rolspelers wat by die produksieproses betrokke is. Hierdie fokusverskuiwing laat die vertaalteorie nader beweeg aan wat werklik in die vertaalbedryf gebeur en soos dit in kwaliteitstandaarde beskryf word.

Vyf kwaliteitstandaarde vir die vertaalbedryf word kortliks in afdeling 2 bekendgestel. In afdeling 3 word die kwaliteitbestuuraksies beskryf wat in minstens drie van die standaarde

2 Verdere voorbeelde van die tipe inligting wat in die vertaalopdrag vervat kan word, word in afdeling 3.1.4 gegee.

3 Dit stem ooreen met die "fit for purpose"-beginsel (ISO s.j.(a)) in die vertaalbedryf. 
vereis word. Verskille en ooreenkomste tussen die siening van kwaliteit in die vertaalbedryf en in die vertaalteorie word uitgewys, waar van toepassing.

\section{Kwaliteitstandaarde vir die vertaalbedryf}

Die ontstaan van kwaliteitstandaarde en kwaliteitbestuur (quality management) word gesien as 'n uitvloeisel van pogings om ná die Tweede Wêreldoorlog die prosesse wat in die vervaardigingsbedryf gevolg is, te standaardiseer (Petersen 1996:208). 'n Voorbeeld hiervan is die Internasionale Standaardiseringsorganisasie (ISO) ${ }^{4}$ se ISO 9000-reeks standaarde, wat verskeie aspekte van kwaliteitbestuurstelsels behels (ISO s.j.(c)) en ook deur talle vertaaldiensverskaffers gebruik is. Dit is egter nie altyd so positief in die vertaalbedryf ontvang nie (Ørsted 2001:443), aangesien vertaling as 'n unieke skeppingsproses beskou word en so konteksspesifiek is. Gehaltevlakke wat in een situasie as aanvaarbaar beskou kan word (bv. een fout in 'n informele e-pos), kan lynreg van 'n ander situasie verskil (bv. een fout in 'n regskontrak). Nasionale standaarde spesifiek vir die vertaalbedryf het dus sedert die 1990's in lande soos Italië, ${ }^{5}$ Duitsland ${ }^{6}$ en Oostenryk ${ }^{7}$ verskyn (kyk Corpas Pastor 2006 en Stejskal 2009 vir 'n oorsig van hierdie nasionale standaarde).

Faktore soos die internet en globalisering het die vertaalbedryf egter in so 'n mate verander dat nasionale standaarde nie meer voldoende was nie en dat vertaaldiensverskaffers en kliënte standaarde nodig gehad het wat in meer lande sou kon geld. Die eerste sodanige standaard, EN 15038, is in 2006 in Europa uitgegee. Vervolgens word vyf van die kwaliteitstandaarde vir die vertaalbedryf wat sedert 2006 gepubliseer is kortliks bekendgestel. Elke standaard beskryf 'n produksieproses wat gevolg moet word om die vertaling te skep, gee vereistes ten opsigte van hulpbronne, en verduidelik terminologie wat in die standaarde gebruik word.

Soos hierbo genoem is, is die nasionale standaarde in 2006 vervang deur die Europese standaard EN 15038 Translation services - Service requirements, wat die Europese Komitee vir Standaardisasie (CEN) in samewerking met verskeie belanghebbendes ontwikkel het (Bonnet 2006:46). Een van die aspekte wat hierdie standaard van ander onderskei, is dat revisie 'n verpligte kontrolemeganisme is (kyk afdeling 3.3.1).

In 'n internasionale opname oor vertaalkwaliteit en -tegnologie wat die Vereniging vir Globalisering en Lokalisering in 2013 onder bykans 500 vertaaldiensverskaffers gedoen het, is bevind dat EN 15038 die gewildste kwaliteitstandaard was (30\% van respondente), gevolg deur die ISO 9000-reeks (27\% van respondente) (Doherty et al. 2013:4). Hoewel EN 15038 in 2015 deur ISO 17100 vervang is, is heelwat standaarde wat ná 2006 gepubliseer is deur hierdie Europese standaard beïnvloed.

4 ISO is 'n onafhanklike, internasionale nieregeringsorganisasie wat deur middel van sy lede (ongeveer 160 nasionale standaardisasieorganisasies) kundiges byeenbring om kennis te deel en vrywillige, konsensusgebaseerde, internasionale standaarde te ontwikkel wat innovasie ondersteun en oplossings vir wêreldwye uitdagings verskaf (ISO s.j.(b)).

5 Die standaard UNI 10574 Definition of services and activities of translation and interpreting enterprises is in 1996 gepubliseer.

6 Die standaard DIN 2345 Translation contracts is in 1998 gepubliseer.

7 Die standaard Önorm D1200 Requirements for the service and the provision of the service en die standaard Önorm D1201 Translation contracts is in 2000 gepubliseer. 
Die standaard CAN/CGSB 131.10 Translation services is deur die Kanadese Raad vir Algemene Standaarde ontwikkel en in 2008 uitgegee. Hierdie kwaliteitstandaard is sterk op EN 15038 (2006) gegrond. Waar daar van die Europese standaard afgewyk word, weerspieël dit die Kanadese perspektief, byvoorbeeld dat revisie nie vereis word nie, maar dat die vertaaldiensverskaffer die behoefte aan revisie sal identifiseer deur die vertaler se vermoëns, die kliënt se vereistes en die aard van die vertaalopdrag in ag te neem (CAN/CGSB 2008:iv, 7).

ISO het die standaard ISO/TS 11669 Translation projects - General guidance in 2012 uitgegee, wat as 'n "technical specification" geklassifiseer word. 'n Konsepstandaard word as 'n internasionale standaard gepubliseer wanneer minstens $75 \%$ van die ISO-lidlande wat daaroor stem hulle goedkeuring gee (ISO/TS 2012:iv). Die konsepstandaard kan egter as 'n "technical specification" uitgegee word (i) wanneer daar 'n dringende behoefte aan 'n standaard in die mark is, en (ii) indien twee derdes van die tegniese komitee wat die dokument voorberei het daartoe instem (ISO/TS 2012:iv). ISO/TS 11669 (2012) is in 2015 hersien en sonder veranderinge vir 'n verdere drie jaar bevestig. Volgens ISO se hersieningsproses behoort 'n volgende hersiening van hierdie standaard in 2018 te geskied, waarna dit óf as 'n internasionale standaard gepubliseer óf onttrek moet word (ISO/TS 2012:iv).

Die uitgangspunt in hierdie standaard is dat die kliënt en die vertaaldiensverskaffer moet saamwerk om gestruktureerde projekspesifikasies te ontwikkel oor die wyse waarop die vertaalprojek uitgevoer sal word. Hierdie spesifikasies kan dan as 'n maatstaf dien waaraan die gehalte van die projek gemeet word (ISO/TS 2012:v), byvoorbeeld in watter mate gehalteversekeringsprosedures gevolg is en of die vertaalproduk teen die ooreengekome sperdatum aan die kliënt gelewer is.

Daar word heelwat ekstra inligting gegee oor byvoorbeeld verskillende soorte vertaaldiensverskaffers (soos vryskutvertalers en vertaalmaatskappye) en hoe om 'n geskikte vertaaldiensverskaffer vir 'n spesifieke projek te identifiseer (ISO/TS 2012:6). Die standaard bied ook meer inligting oor content correspondence, wat verduidelik word as "how the target content matches the source content" (2012:22). Tipiese soorte content correspondence word dan genoem, met verwysings na onder andere House (1997), Nord (1997) en Vermeer (1996), en word verder beskryf: koverte en overte vertaling (covert vs. overt), volle en opsommende vertaling (full translation vs. summary translation), akkuraatheid (accuracy), vlotheid (fluency) wat leesbaarheid insluit, en laastens, idiomatiese en nie-idiomatiese vertaling (idiomatic vs. non-idiomatic) (ISO/TS 2012:22-24). ISO/TS 11669 (2012) is die enigste kwaliteitstandaard vir die vertaalbedryf wat nie net na vorige standaarde verwys nie, maar ook vertaalteoretiese verwysings insluit.

In 2006 het ASTM Internasionaal ${ }^{8}$ die standaard ASTM F2575 Standard guide for quality assurance in translation die eerste keer uitgegee. 'n Hersiene weergawe het in 2014 verskyn met een afdeling (specifications phase) wat bygewerk en uitgebrei is. Hierdie Amerikaanse standaard is in wese ' $n$ riglyn: Dit bied meer inligting oor vertaling en die produksieproses van 'n vertaling, erken die uniekheid van vertaalprojekte en beveel dus nie spesifieke optrede aan nie. Die standaard verskaf 'n raamwerk waarbinne die vertaaldiensverskaffer en die kliënt 'n ooreenkoms oor spesifikasies vir 'n vertaalprojek kan aangaan. Hulle kan dus die prosesse

8 ASTM Internasionaal het voorheen as die American Society for Testing and Materials bekend gestaan. Dit is een van die grootste organisasies wêreldwyd wat vrywillige standaarde vir materiaal, produkte, stelsels en dienste ontwikkel (Colina 2008:99). 
definieer wat nodig is om 'n vertaalproduk van geskikte gehalte te skep wat aan die teikenleser se verwagtinge en behoeftes sal voldoen (ASTM 2014:1).

Die standaard ISO 17100 Translation services - Requirements for translation services is in 2015 uitgegee. Dit is gebaseer op én vervang die Europese standaard EN 15038 (ISO Quality Services Bpk. 2015). Soos die ander kwaliteitstandaarde, verskaf ISO 17100 vereistes ten opsigte van kernprosesse, hulpbronne en ander aspekte wat nodig is om 'n vertaaldiens van hoogstaande gehalte te lewer (ISO 2015:1), en is gerig op vertaaldiensverskaffers van alle groottes (ISO 2015:vi).

Dit is van kardinale belang dat vertaaldiensverskaffers die kwaliteitbestuurriglyne in hierdie vyf standaarde volg, veral aangesien die vertaalberoep ongereguleerd is. Die Wet op die SuidAfrikaanse Taalpraktisynsraad (no. 8 van 2014) maak daarvoor voorsiening dat hierdie statutêre liggaam die professionele status van taalpraktisyns sal verhoog deur byvoorbeeld opleiding en akkreditasie te reguleer (RSA 2014). Daar is egter sedert die bekragtiging van die wet min vordering met die samestelling van hierdie raad gemaak (SAVI 2017:5-6). Vertaaldiensverskaffers in Suid-Afrika - byvoorbeeld vertaalkantore aan hoëronderriginstellings - kan wel die kernstappe vir kwaliteitbestuur volg wat in die meeste vertaalstandaarde voorkom. In afdeling 3 word hierdie kernstappe in die konteks van 'n akademiese vertaalkantoor beskryf en, waar van toepassing, met vertaalteoretiese beginsels in verband gebring.

\section{Kernstappe vir kwaliteitbestuur in vertaling}

Die produksieproses van vertalings word in tabel 1 aan die hand van Drugan (2013:77-80) in die voorvertaal-, vertaal- en navertaalfase ingedeel. Hierdie indeling weerspieël die konteks van talle akademiese vertaalkantore waar projekkoördineerders vertaalwerk aan interne en/of vryskutvertalers toeken en die kwaliteitkontrole in die kantoor gedoen word.

Die voorvertaalfase behels hoofsaaklik standaardstelsels wat vir bykans elke kliënt gebruik word, soos prosedures vir die aanstelling van vertalers, en projekbestuurstelsels waardeur die besonderhede van elke vertaalprojek aangeteken word (Drugan 2013:77-78). Een van die belangrikste aksies in hierdie fase is om 'n ooreenkoms met die kliënt aan te gaan waarin byvoorbeeld die taalkombinasie, leweringsdatum en tarief vir die vertaling gespesifiseer word (Drugan 2013:78). Die vertaalfase begin wanneer die vertaalkantoor die bronteks, vertaalopdrag en ander relevante materiaal aan die vertaler stuur; die vertaler skep die vertaling in ooreenstemming met die vertaalopdrag, doen selfrevisie en stuur die vertaling teen die ooreengekome leweringsdatum aan die vertaalkantoor (Drugan 2013:78-79). Die navertaalfase behels aksies soos geskikte kwaliteitkontrole (wat revisie kan insluit) en om terugvoer van die kliënt te kry (Drugan 2013:79-80).

Tabel 1 dui kernaksies en -inligting aan wat in minstens drie kwaliteitstandaarde vereis word. 
Tabel 1: Kernstappe vir kwaliteitbestuur in standaarde vir die vertaalbedryf

\begin{tabular}{|l|}
\multicolumn{1}{|c|}{ Voorvertaalfase } \\
\hline Die vertaalkantoor en kliënt gaan 'n skriftelike ooreenkoms aan. \\
\hline Ken geskikte menslike hulpbronne aan die vertaalprojek toe. \\
\hline Versamel tekstuele hulpbronne wat tot die gehalte van die vertaling kan bydra. \\
\hline Sluit soveel besonderhede moontlik by die vertaalopdrag in. \\
\hline \multicolumn{1}{|c|}{ Vertaalfase } \\
\hline Die vertaler skep die vertaling. \\
\hline Die vertaler doen selfrevisie voordat die vertaling aan die vertaalkantoor gestuur word. \\
\hline \\
\hline Eerste kwaliteitkontrole: revisie \\
\hline Tweede kwaliteitkontrole: vakkundige redigering \\
\hline Derde kwaliteitkontrole: proeflees \\
\hline $\begin{array}{l}\text { Evalueer die vertaalprojek aan die hand van die ooreenkoms met die kliënt voordat die vertaling aan } \\
\text { die kliënt gelewer word. }\end{array}$ \\
\hline Kry terugvoer van die kliënt. \\
\hline
\end{tabular}

Hierdie riglyne oor hulpbronne en kernstappe in die produksieproses word nou kortliks bespreek en in die konteks van 'n akademiese vertaalkantoor geplaas.

\subsection{Voorvertaalfase}

Die voorvertaalfase begin wanneer 'n moontlike kliënt die vertaalkantoor versoek om 'n vertaalprojek te hanteer, en eindig sodra die projekkoördineerder die bronteks en ander relevante dokumente aan die vertaler gestuur het.

\subsubsection{Skriftelike ooreenkoms}

Die EN 15038-standaard bevat die minste inligting oor die skriftelike ooreenkoms wat tussen die vertaalkantoor en die kliënt aangegaan word: Die ooreenkoms moet die bedryfsvoorwaardes en diensspesifikasies bevat en moontlik ook aspekte soos kopiereg, aanspreeklikheid, vertroulikheid, geskilbeslegting en kwaliteitversekering (quality assurance) (2006:8-9). In CAN/CGSB 131.10 word aspekte met betrekking tot die vertaling self bygevoeg, soos 'n beskrywing van die bronteks, spesifieke vereistes wat betref terminologie, en of daar enigsins van die vertaalkantoor se standaardprosedures afgewyk moet word (2008:4-5). Die ISO 17100standaard bevat 'n lys van moontlike aspekte (2015:13-14), byvoorbeeld dat die kliënt moet 
poog om die brontaalinligting elektronies aan die vertaalkantoor te stuur en dat daar ooreengekom moet word of die vertaalkantoor of vertaler erkenning vir die vertaling sal ontvang (2015:14).

Die ander twee kwaliteitstandaarde beskryf in veel meer besonderhede watter kwessies bespreek en gefinaliseer moet word voordat die vertaalprojek kan begin: Die ASTM F2575standaard beskryf 'n spesifikasiefase waarin daar inligting verskaf en ooreengekom moet word oor (i) produkparameters soos die bronteks en die doelteks, (ii) prosesparameters soos watter kwaliteitversekering toegepas sal word, en (iii) projekparameters soos watter verwysingsmateriaal gebruik kan word en oor watter kwalifikasies en/of akkreditasie rolspelers in die produksieproses moet beskik (2014:7-10). Verreweg die meeste besonderhede word in ISO/TS 11669 verskaf, waar 21 vertaalparameters (met verdere onderafdelings) in vier kategorieë verdeel word, naamlik parameters wat betref (i) taal, (ii) produksietake, (iii) die vertaalomgewing, en (iv) verhoudinge tussen rolspelers (2012:16) met beskrywings, notas en voorbeelde by elke parameter (2012:18-28).

'n Skriftelike ooreenkoms tussen die vertaalkantoor en kliënt is belangrik in die geval van uitgebreide vertaalprojekte waar verskeie dokumente en tale betrokke is, en veral wanneer die verhouding tussen die vertaalkantoor en die kliënt nog nuut is. Vertaalkantore het egter ook gereelde kliënte waar die verhouding van so 'n aard is dat heelwat van die projekspesifikasies wat in kwaliteitstandaarde genoem word, implisiet is en dit nie prakties is om dit telkens in 'n skriftelike ooreenkoms te beskryf nie.

\subsubsection{Geskikte menslike hulpbronne vir die vertaalprojek}

Die fokus van die kwaliteitstandaarde is op duidelike kommunikasie tussen die vertaalkantoor en die kliënt, en daarom word daar ten opsigte van die toekenning van hulpbronne aan 'n vertaalprojek slegs genoem dat geskikte interne en/of eksterne menslike hulpbronne gebruik moet word om te verseker dat die vereistes in die ooreenkoms met die kliënt nagekom word (ASTM 2014:10; CAN/CGSB 2008:6; EN 2006:10; ISO 2015:8).

Die huidige internasionale en nasionale ekonomiese klimaat plaas egter druk op hoëronderriginstellings en akademiese vertaalkantore om al hoe meer met al hoe minder personeel te bereik in 'n poging om volhoubare dienste te lewer. Dit veroorsaak hoë tyddruk en vereis van personeel om te prioritiseer en nét genoeg tyd aan 'n spesifieke projek te bestee. Dit veroorsaak ook dat vertaalkantore prosedures moet hê om personeel te kies wat die geskikste vaardighede vir 'n spesifieke projek het.

\subsubsection{Voldoende tekstuele hulpbronne/verwysingsmateriaal}

Relevante stylgidse, glossariums en tweetalige termdatabasisse is voorbeelde van ekstra hulpbronne wat gebruik kan word om die gehalte van die vertaling, byvoorbeeld in terme van konsekwentheid, te verhoog (ASTM 2014:9; CAN/CGSB 2008:5; ISO 2015:9; ISO/TS 2012:27). Die gebruik van 'n stylgids is belangrik, veral vir vertaalkantore wat van vryskutvertalers se dienste gebruik maak, aangesien hulle nie soos interne vertalers gereelde vergaderings oor stylaspekte kan bywoon nie. EN 15038 (2006:16) lys verskeie aspekte wat in so 'n stylgids opgeneem kan word, byvoorbeeld die vertaalkantoor se stylkeuses ten opsigte van punktuasie, afkortings en akronieme, die formaat van telefoonnommers, en algemene foute wat vermy moet word, soos onvanpaste register en taalinterferensie (bv. anglisismes en valse 
vriende). 'n Voorbeeld van 'n vertaalkantoor-stylgids is die US Taalsentrum se Afrikaanse en Engelse stylgidse (US Taalsentrum 2012; 2014), wat ook riglyne oor wetenskaplike skryfwerk bevat.

Terminologiebestuur is van die uiterste belang vir die sukses van 'n vertaalprojek en behoort deurlopend plaas te vind (ASTM 2014:10; ISO/TS 2012:11) deur byvoorbeeld enige projekspesifieke terminologie met die kliënt uit te klaar. Indien dit nie gedoen word nie, kan dit gebeur dat die vertaler ekstra tyd aan die navorsing van terme bestee, wat later in die produksieproses kan veroorsaak dat reviseurs genoop word om veranderinge aan te bring wat deur die gebruik van 'n terminologielys verhoed sou kon word. Dit is veral belangrik in groot projekte waarby meer as een vertaler betrokke is: Die vertalers gebruik die aanvanklike terminologielys as riglyn en voeg verdere terme by sodra die vertalings met die kliënt uitgeklaar is. In ISO/TS 11669 (2012:31) word daar basiese riglyne oor die hantering van terminologie in 'n vertaalprojek gegee. Dit sluit in dat die bronteks ontleed moet word om moontlike vertaalprobleme te bepaal en om terminologie te identifiseer sodat gepaste vertalings daarvoor met die kliënt ooreengekom kan word (EN 2006:10; ISO 2015:9; ISO/TS 2012:31). So 'n ontleding kan ook bronteksspesifieke faktore identifiseer wat die vertaling sou kon bemoeilik, soos inkonsekwente terminologiegebruik, 'n tekort aan kohesie, grammatika- of spelfoute, en inkonsekwente formatering (ISO/TS 2012:20).

Terminologiebestuur kan vergemaklik word deur, wanneer moontlik, 'n kliënt se vertaalwerk aan 'n spesifieke vertaler toe te ken. Op hierdie manier leer die vertaler die kliënt se styl- en terminologievoorkeure ken, en hoef die reviseur minder tyd aan die revisie van die vertaling te bestee.

\subsubsection{Vertaalopdrag}

Die vertaalopdrag bevat inligting oor die spesifikasies wat in die vertaalprojek nagekom moet word (ASTM 2014:10; CAN/CGSB 2008:6; EN 2006:11; ISO 2015:10; ISO/TS 2012:13). Hierdie inligting moet gedokumenteer en aan die rolspelers soos die vertaler en reviseur gekommunikeer word. Die kwaliteitstandaarde verwys na hierdie dokument as die project assignment (CAN/CGSB en EN), project specifications (ISO/TS), specifications agreement (ASTM) en translation service specifications (ISO). Soos in afdeling 1 genoem, bepaal funksionalistiese vertaalteorieë dat daar 'n vertaalopdrag (translation brief) geskep moet word met soveel moontlik inligting oor die situasie waarin die doelteks gebruik sal word (Nord 2010). Holz-Mänttäri gebruik die term "product specification" (1984, soos deur Venuti 2004:222-223 uit Duits vertaal) wat ooreenstem met die terme wat in die kwaliteitstandaarde gebruik word.

Volgens sowel funksionalistiese vertaalteorieë as kwaliteitstandaarde is van die aspekte wat in die vertaalopdrag beskryf kan word die taalkombinasie, tekstipe (bv. jaarverslag of eksamenvraestel), vakgebied (bv. geografie en geskiedenis), die teikenlesers (bv. hoe oud hulle is en of hulle leke of deskundiges op die vakgebied is), die doel van die vertaling (m.a.w. waar en hoe die vertaling gebruik sal word), en in watter mate die inhoud van die bronteks en doelteks moet ooreenstem (bv. 'n meer direkte vertaling van 'n regsteks soos 'n kontrak, of 'n aanpassing van die bewoording in wetgewing om dit vir 'n breër lesersgroep toeganklik te maak). In die praktyk is dit baie keer moeilik om al hierdie inligting by die kliënt te kry. Tog dra dit by tot die kwaliteitversekering van die vertaalproduk. Die rolspelers kan na die vertaalopdrag verwys om seker te maak dat die vertaalprojek aan die kliënt se vereistes voldoen, en sodoende kan die vertaalopdrag gebruik word om die vertaalprojek te evalueer. 


\subsection{Vertaalfase}

Die vertaalfase begin wanneer die vertaalkantoor die bronteks, vertaalopdrag en ander relevante materiaal aan die vertaler stuur, en eindig wanneer die vertaler die doelteks aan die vertaalkantoor stuur. Dit kan deur 'n interne vertaler of 'n vryskutvertaler hanteer word.

\subsubsection{Die vertaler skep die vertaling9}

Die vertaler se taak is om die vertaling te skep in ooreenstemming met die instruksies in die vertaalopdrag, en met die volgende aspekte in gedagte wat in die vertaalopdrag gespesifiseer kan word (CAN/CGSB 2008:6-7; EN 2006:11; ISO 2015:10; ISO/TS 2012:13, 21-25):

- Enige addisionele gegewe dokumentasie, soos 'n stylgids, glossariums, terminologielyste of reeds vertaalde dokumente vir dieselfde kliënt of op dieselfde vakgebied;

- die teikenlesers en die doel van die vertaling;

- gepaste terminologie vir die vakgebied en die spesifieke kliënt;

- die akkurate oordrag van die inligting in die bronteks volgens die verwagte "content correspondence" (ISO/TS 2012:22);

- korrekte grammatika, spelling, punktuasie en tipografie;

- idiomatiese doeltaalgebruik;

- gepaste styl, register en taalvariante/-dialekte; en

- uitleg en formatering.

\subsubsection{Die vertaler doen selfrevisie}

Mossop (2014) se onderskeid tussen selfrevisie en anderrevisie is hier van toepassing: Die vertaler moet self die vertaling nagaan (selfrevisie) om seker te maak dat dit aan die instruksies in die vertaalopdrag voldoen (kyk afdeling 3.2.1), en moet die nodige veranderinge aanbring voordat dit aan die vertaalkantoor gestuur word (CAN/CGSB 2008:7; EN 2006:11; ISO 2015:10; ISO/TS 2012:26). Revisie word daarna deur 'n ander persoon gedoen (anderrevisie), soos in afdeling 3.3 .1 beskryf.

\subsection{Navertaalfase}

Die navertaalfase begin sodra die vertaalkantoor die doelteks van die vertaler ontvang, en eindig wanneer die projek op die betrokke stelsels afgesluit word. Die aantal en aard van die aksies in hierdie fase wissel na gelang van die omvang en aard van die vertaalprojek, die vertaalkantoor se hulpbronne en benadering tot kwaliteitbestuur, en die ooreenkoms wat die vertaalkantoor met die kliënt aangegaan het. Volgens ISO/TS 11669 (2012:26) kan dieselfde persoon in 'n uiters eenvoudige vertaalprojek vir die vertaling, selfrevisie én revisie verantwoordelik wees,

9 ISO/TS 11669 (2012:13) maak daarvoor voorsiening dat hierdie konsepvertaling deur 'n mens of 'n masjien gedoen word. Soos in afdeling 3.4.5 aangedui, veroorsaak die voortdurende ontwikkelinge ten opsigte van tegnologiese hulpbronne egter dat die gebruik van vertaalgeheues en masjienvertaling nie in besonderhede in die kwaliteitstandaarde beskryf word nie. 
terwyl meer persone in 'n komplekse vertaalprojek by elke fase betrokke sal wees. Dít is egter 'n afwyking van die terminologie wat Mossop $(2014: 226,228)$ gebruik: Dieselfde persoon kan nie sowel selfrevisie as anderrevisie op dieselfde dokument uitvoer nie. As die vertaling nie deur iemand anders as die vertaler nagegaan is nie, beteken dit dat die vertaalkantoor nie die (ander)revisie-kwaliteitkontrole (afdeling 3.3.1) uitgevoer het nie.

\subsubsection{Eerste kwaliteitkontrole: Revisie}

Die vertaling word gelees om enige foute te korrigeer sowel as om "its suitability for purpose" na te gaan (EN 2006:11; ISO 2015:11). Dit sluit in om terminologie te verifieer en volledigheid en content correspondence na te gaan (ISO/TS 2012:26). Benewens hierdie aspekte, noem die Amerikaanse standaard ook akkuraatheid, koherensie en leesbaarheid (ASTM 2014:10) en gee CAN/CGSB 131.10 die meeste besonderhede deur konsekwentheid, register, toon, styl, grammatika en spelling by te voeg (2008:7). Dit weerspieël die kriteria wat in afdeling 3.2.1 genoem is wat die vertaler in die skep van die vertaling moet volg. Dit is van kardinale belang dat die reviseur ook die vertaalopdrag ontvang ten einde seker te mak of die vertaler die instruksies gevolg het.

Die meeste kwaliteitstandaarde noem dat die reviseur iemand anders as die vertaler moet wees (CAN/CGSB 2008:7; EN 2006:11; ISO 2015:10; ISO/TS 2012:6), met kwalifikasies en vaardighede soos in afdeling 3.4.2 beskryf. Die enigste riglyn oor die revisiemetode is dat die reviseur die doelteks met die bronteks moet vergelyk (EN 2006:11; ISO 2015:11; ISO/TS 2012:26). Die Amerikaanse standaard voeg 'n tweede stap by waarvolgens die reviseur op gepaste taalgebruik moet fokus wanneer die hele doelteks deurgelees word en slegs na die bronteks moet verwys indien nodig (ASTM 2014:10).

Revisie is in sommige standaarde 'n vereiste (EN 2006:11; ISO 2015:10), terwyl ASTM F2575 dit slegs as 'n geleentheid beskryf om seker te maak dat die vertaling aan die projekspesifikasies voldoen (2014:10). Die kliënt se insette hieroor word in die ander kwaliteitstandaarde erken deurdat die stap uitgevoer moet word wanneer dit in die projekspesifikasies tussen die vertaalkantoor en kliënt ooreengekom is (ISO/TS 2012:6). Volgens die Kanadese standaard bepaal die vertaalkantoor of dit nodig is om revisie te doen deur die vertaler se vaardighede, die kliënt se vereistes en die aard of kompleksiteit van die spesifieke projek in ag te neem (CAN/CGSB 2008:7).

Revisie is ' $n$ redelik nuwe studieveld in die vertaalteorie. Empiriese studies toon dat reviseurs nie noodwendig die gehalte van die konsepvertaling verbeter nie (kyk bv. Ipsen en Dam 2016; Künzli 2007; Van Rensburg 2012, Ter perse). Handboeke soos dié van Mossop (2014) verskaf wel riglyne oor revisie, maar daar is ' $n$ tekort aan revisieopleiding, en sover bekend, is daar tans slegs twee revisievermoëmodelle, naamlik dié van Hansen (2008) en Robert, Remael en Ureel (2017) wat empiries ondersoek word. Empiriese navorsing oor revisie is juis belangrik vir vertaalkantore, aangesien goeie vertalers nie noodwendig goeie reviseurs is nie (Hansen 2008). Verder is hierdie kwaliteitkontrole duur in terme van tyd en geld, en kan vertaalkantore genoop word om risiko's en hulpbronne teen mekaar op te weeg deur byvoorbeeld te besluit om minder belangrike dokumente wat deur 'n goeie vertaler vertaal is, nie vir revisie te stuur nie (Martin 2007; Prioux en Rochard 2007). 


\subsubsection{Tweede kwaliteitkontrole: Vakkundige redigering}

Hierdie stap word in al die kwaliteitstandaarde as opsioneel aangedui en die Engelse term wat daarvoor gebruik word, is review. Dit behels ' $\mathrm{n}$ eentalige redigering van die doelteks om te bepaal of die vakkundige inhoud akkuraat en gepas is vir die spesifieke vakgebied en vertaalopdrag, en of die konvensies van die vakgebied en tekstipe gevolg word (ASTM 2014:7, 9; CAN/CGSB 2008:8; EN 2006:11; ISO 2015:11; ISO/TS 2012:26).

Wanneer die vertaler van byvoorbeeld klasnotas ervare is op daardie betrokke vakgebied, en daar nie 'n reviseur beskikbaar is wat dieselfde ervaring het nie, is dit moontlik om die revisiestap uit te laat en die vakkundige redigering deur die betrokke dosent te laat doen.

\subsubsection{Derde kwaliteitkontrole: Proeflees}

Die kwaliteitstandaarde gee baie min inligting oor hierdie stap. Die hoofrede hiervoor kan wees dat dit van die aard en omvang van die vertaalprojek afhang of hierdie derde kwaliteitkontrole gedoen word. Proeflees word gewoonlik gedoen wanneer die vertaling gepubliseer sal word (EN 2006:12; ISO 2015:11): Dit is 'n eentalige lees van die doelteks met die fokus op taalgebruik, maar veral op tipografiese en formateringskwessies (ASTM 2014:3, 10).

\subsubsection{Evalueer vertaalprojek}

Die vertaaldiensverskaffer evalueer die hele vertaalprojek en maak seker dat die spesifikasies in die ooreenkoms met die kliënt nagekom is (ASTM 2014:10; EN 2006:12; ISO 2015:11; ISO/TS 2012:13). Dit geld veral vir groter vertaalprojekte waar daar 'n spesifieke ooreenkoms opgestel is.

\subsubsection{Terugvoer}

Terugvoer van die kliënt kan waardevol wees om voortdurende verbetering te verseker, en behoort met die betrokke rolspelers gedeel te word (ASTM 2014:11; ISO 2015:11; ISO/TS 2012:14). Dit kan op 'n formele wyse deur die vertaalkantoor hanteer word, soos vraelyste aan kliënte, en sporadiese informele kliënteterugvoer kan ook aan spanlede gestuur word.

\subsection{Hulpbronne}

\subsubsection{Vertalers se kennis, vermoëns en kwalifikasies}

Die bespreking van riglyne in kwaliteitstandaarde ten opsigte van die kennis en vermoëns waaroor vertalers behoort te beskik, word op Van Rensburg (2014:570-572) se indeling gebaseer en in tabel 2 met inligting uit die twee jongste standaarde - ASTM F2575 (2014) en ISO 17100 (2015) - bygewerk. 
Tabel 2: Vereistes ten opsigte van vertalers se kennis en vermoëns

\begin{tabular}{|l|l|}
\hline \multicolumn{1}{|c|}{ Brontaal en doeltaal } & \multicolumn{1}{c|}{ Vakgebied } \\
\hline Kulturele aspekte t.o.v. bron- en doeltaal & $\begin{array}{l}\text { Vertaalopdrag: ontleed en lewer 'n produk wat aan die } \\
\text { kliënt se spesifikasies voldoen }\end{array}$ \\
\hline Navorsing & Vertaalprosesse en die oplos van vertaalprobleme \\
\hline Tegnologie & Vlakke van vertaling \\
\hline Tekstipe & Voortgesette professionele ontwikkeling \\
\hline
\end{tabular}

Daar is 'n sterk ooreenkoms tussen die literatuur oor vertaalvermoëmodelle (kyk bv. EMT Expert Group 2009; Göpferich 2009, 2013; Göpferich et al. 2011; Hurtado Albir 2015; PACTE 2008, 2011, 2014) en die kennis en vaardighede wat die vyf kwaliteitstandaarde van vertalers vereis. Vertalers behoort oor voldoende bron- en doeltaalkennis te beskik om die bronteks te verstaan en die boodskap in 'n idiomatiese doeltaal oor te dra. Daar word in die vertaalbedryf aanbeveel dat vertalers uit hulle tweede taal (die taal van die bronteks) in hulle eerste taal (die taal van die doelteks) vertaal. ISO/TS 11669 (2012:8) en ASTM F2575 (2014:6) erken egter die kompleksiteit en uniekheid van vertaalsituasies en maak daarvoor voorsiening dat vertalers in hulle tweede taal vertaal.

Vertalers moet die vertaalopdrag ontleed en geskikte probleemoplossingstegnieke en vertaalprosesse aan die dag lê ten einde 'n vertaling te skep wat aan die vereistes in die vertaalopdrag voldoen. Dit is belangrik dat die doel van die vertaling en die profiel van die teikenlesers in die vertaalopdrag beskryf word. Vertalers het hierdie inligting nodig om te bepaal wat die geskikte vlak van vertaling sal wees: 'n Rowwe vertaling van 'n informele e-pos is voldoende, maar ' $\mathrm{n}$ afgeronde vertaling word vereis van byvoorbeeld 'n vraelys wat vir navorsingsdoeleindes gebruik sal word (ASTM 2014:7).

Kennis van die betrokke vakgebied en tekstipe, sowel as 'n begrip van die bron- en doeltaalkultuur, is van die uiterste belang. Verder moet vertalers tegnologiese en navorsingsvaardighede aan die dag lê om, waar nodig, bykomende linguistiese en vakkennis in te win. Die verantwoordelikheid vir die voortgesette professionele ontwikkeling van vertalers lê nie net by vertaalkantore nie (kyk afdeling 3.4.4), maar ook by die vertalers self (ISO/TS 2012:8). Sosiale vaardighede word ook in ISO/TS 11669 (2012:7) genoem, aangesien vertalers doeltreffend in vertaalspanne moet kan funksioneer.

Akademiese vertaalkantore het selde die kapasiteit om vertalers se vaardighede ten opsigte van al die aspekte in tabel 2 te toets. Van Rensburg (2014:572-573) se indeling van riglyne oor moontlike aanduidings van vertalers se kennis en vaardighede is as basis vir die inligting in tabel 3 gebruik en met nuwe inligting uit die twee jongste standaarde bygewerk. 
Tabel 3: Moontlike aanduidings van vertalers se kennis en vaardighede

\begin{tabular}{|c|l|}
\hline \multirow{2}{*}{ Taalvermoë } & $\begin{array}{l}\text { Resultate van gestandaardiseerde taalvaardigheidstoetse soos die } \\
\text { TOEFL(Test of English as a Foreign Language)-toets }\end{array}$ \\
\cline { 2 - 3 } & $\begin{array}{l}\text { Aantal jaar studie aan 'n hoëronderriginstelling, en erkende graad in bron- } \\
\text { en/of doeltaal verwerf }\end{array}$ \\
\cline { 2 - 2 } & Aantal jaar verblyf in land(e) waar die bron- en/of doeltaal gepraat word \\
\hline \multirow{2}{*}{ Vertaalvermoë } & $\begin{array}{l}\text { Akkreditasie by 'n professionele vertaalorganisasie soos SAVI (Suid- } \\
\text { Afrikaanse Vertalersinstituut), wat 'n lid van FIT (Internasionale Federasie } \\
\text { van Vertalers) is }\end{array}$ \\
\cline { 2 - 2 } & \begin{tabular}{l} 
'n Erkende graad in vertaling aan 'n hoëronderriginstelling \\
\cline { 2 - 3 } Persoonlike verwysings m.b.t. gehalte van vorige vertaalwerk
\end{tabular} \\
\cline { 2 - 2 } Vakgebied & $\begin{array}{l}\text { Aantal jaar studie aan 'n hoëronderriginstelling, en erkende graad op die } \\
\text { betrokke vakgebied verwerf }\end{array}$ \\
\hline \multirow{2}{*}{$\begin{array}{c}\text { Taal-, vertaalvermoë } \\
\text { en vakgebied }\end{array}$} & $\begin{array}{l}\text { Aantal jaar bewese ervaring as 'n professionele vertaler in die spesifieke } \\
\text { taalkombinasie en/of op die spesifieke vakgebied }\end{array}$ \\
\hline
\end{tabular}

Volgens ISO 17100 (2015:6) en EN 15038 (2006:7) behoort vertalers oor minstens een van die volgende te beskik: i) 'n erkende graad in vertaling aan 'n hoëronderriginstelling, ii) 'n erkende graad op enige vakgebied, plus minstens twee jaar voltydse professionele ervaring in vertaling, en iii) minstens vyf jaar voltydse professionele ervaring in vertaling. Die Kanadese standaard vereis of 'n graad in vertaling óf "[p]rofessional designation as a certified translator" (CAN/CGSB 2008:3), maar sommige voornemende kliënte is dalk nie daarvan bewus dat die vertaler in die vertaalrigting van die betrokke vertaalprojek geakkrediteer behoort te wees nie.

Die standaarde ASTM F2575 (2014:5-7) en ISO/TS 11669 (2012:7-8) noem veel meer aanduidings van vertalers se kennis en vermoëns, soos in tabel 3 gesien kan word. Dit is belangrik om daarop te let dat taalvermoë afneem wanneer die taal te min gebruik word, en dat ou toetsuitslae dalk nie 'n akkurate weerspieëling van die vertaler se huidige taalvermoë is nie (ASTM 2014:6). Dieselfde geld in die geval van kwalifikasies wat jare gelede verwerf is sonder enige voortgesette professionele ontwikkeling, sowel as wanneer iemand jare gelede 'n voltydse professionele vertaler was, maar sedertdien 'n ander beroep beoefen. Vertaalkantore behoort dus soveel moontlik inligting oor vertalers se ervaring te bekom ten einde die geskikste vertalers vir vertaalprojekte te gebruik.

\subsubsection{Reviseurs se kennis, vermoëns en kwalifikasies}

Daar word geen riglyne oor reviseurs se vermoëns en kwalifikasies in ASTM F2575 gegee nie, en 'n reviseur ${ }^{10}$ word as ' $n$ tweetalige lid van die vertaalspan beskryf (2014:2). In die ander vier standaarde word daar van reviseurs verwag om oor dieselfde vermoëns en kwalifikasies as vertalers te beskik, met bykomende kennis en vermoëns op die betrokke vakgebied. Die ISO/TS-standaard (2012:9) maak melding van 'n uitgebreide kennis, maar laat ruimte daarvoor dat dit aanvaarbaar sal wees as slegs die persoon wat die vakkundige redigering doen oor daardie kennis beskik. Die Kanadese standaard spesifiseer 'n minimum van drie jaar voltydse

10 Die ASTM-standaard (2014) gebruik die term redigeerder (editor) in plaas van reviseur, en redigering (editing) in plaas van revisie. 
vertaalervaring op die betrokke vakgebied, maar revisie-ervaring word nie genoem nie (CAN/CGSB 2008:3). Vertaal- en/of revisie-ervaring op die betrokke vakgebied word in ISO 17100 (2015:6) en EN 15038 (2006:6) vereis.

Daar is in die vertaalteorie nog redelik min empiriese navorsing oor revisie, en spesifiek oor revisievermoë, gedoen. Empiriese studies het wel getoon dat selfs ervare vertalers foute oorsien, onnodige veranderinge aanbring en ook nuwe foute invoeg (Künzli 2007; Van Rensburg 2012, Ter perse). In Hansen (2008) se longitudinale empiriese studie is bevind dat sekere taalpraktisyns vertaalprodukte van hoë gehalte, maar revisieprodukte van lae gehalte gelewer het, terwyl ander weer vertaalprodukte van lae gehalte, maar revisieprodukte van hoë gehalte gelewer het. Dit is duidelik uit die twee bestaande revisievermoëmodelle (Hansen 2008; Robert et al. 2017) dat daar vaardighede is wat deel vorm van sowel revisie- as vertaalvermoë (soos kennis oor die betrokke taalkombinasie en genre), maar dat daar ander vaardighede is wat spesifiek vir revisievermoë geld (soos om te weet wanneer dit gepas is om 'n verandering aan te bring en wanneer nie). Vertaalvermoë kan dus nie met revisievermoë gelykgestel word nie.

\subsubsection{Vakkundige redigeerders se kennis, vermoëns en kwalifikasies}

In die ASTM-standaard (2014:2) word vakkundige redigering as een van die verskeie aspekte van redigering beskou. Die term "monolingual editing" word vir hierdie aksie gebruik (2014:9) en geen riglyne ten opsigte van die persoon wat dit doen, of die sogenaamde "third-party reviewer" (2014:4), word gegee nie. Vakkundige redigeerders is gewoonlik nie vertalers nie, maar wel spesialiste op hulle vakgebied (CAN/CGSB 2008:3; ISO/TS 2012:9). ISO 17100 (2015:6) en EN 15038 (2006:6) vereis dat hulle oor 'n relevante hoëronderrigkwalifikasie en/of ervaring op die vakgebied beskik.

\subsubsection{Voortgesette professionele ontwikkeling}

Volgens drie van die vyf kwaliteitstandaarde vir die vertaalbedryf (EN 2006, ISO 2015 en ISO/TS 2012) behoort die kennis en vermoëns van vertalers, reviseurs en vakkundige redigeerders voortdurend opgeskerp te word. In die Amerikaanse standaard word dit geïmpliseer deur 'n nota wat uitwys dat taalvermoë afneem wanneer die taal nie gebruik word nie (ASTM 2014:6). Dit geld ook vir vertaalvermoë: As 'n vertaler tien jaar gelede SAVIakkreditasie verwerf het, maar in die afgelope vyf jaar min of geen vertaling gedoen het nie, sal die akkreditasie nie meer 'n akkurate aanduiding van daardie persoon se vertaalvermoë wees nie. ${ }^{11}$ Akademiese vertaalkantore behoort minstens hulle interne personeel die geleentheid te bied om professioneel te ontwikkel deur byvoorbeeld werksessies en kongresse by te woon. Vertaalkantore wat nie die kapasiteit of hulpbronne het om gereelde opleiding aan hulle vryskutvertalers te verskaf nie, kan hulle wel aanmoedig om lid van 'n professionele vertaalorganisasie soos SAVI te wees en/of opleidingsgeleenthede deur SAVI en ander instansies by te woon. Vertalers sal nog méér waarde uit SAVI-lidmaatskap kan put as dié professionele vertaalorganisasie sy akkreditasiestelsel aanpas deur 'n komponent vir voortgesette professionele ontwikkeling by te voeg. 'n Voorbeeld van so 'n stelsel is dié van die Amerikaanse vertalersvereniging ATA, wat van geakkrediteerde lede verwag om bewys te

11 Persone wat om lidmaatskap by die Chartered Institute of Linguists in die Verenigde Koninkryk aansoek doen, moet onder andere oor 'n graad in tale/vertaling/tolking beskik. Indien daardie graad egter langer as 12 jaar gelede verwerf is, word daar van die aansoekers verwag om bewys van hulle huidige taalvaardigheid te lewer deur byvoorbeeld 'n eksamen af te lê. (Van Rensburg 2014:569) 
lewer dat hulle in drie jaar ongeveer 20 uur se opleiding ontvang het, anders verbeur hulle hul akkreditasie (Van Rensburg 2014:569).

\subsubsection{Infrastruktuur: Tegniese en tegnologiese hulpbronne}

Die spoed waarteen tegnologie ontwikkel, veroorsaak dat vereistes oor tegniese en tegnologiese hulpbronne in die kwaliteitstandaarde nie in besonderhede beskryf word nie. Daar word slegs genoem dat die nodige harde- en sagteware beskikbaar moet wees en gebruik moet word om kommunikasie te bewerkstellig, dat die vertaalkantoor toegang tot die media en inligtingsbronne moet hê, sowel as tot die nodige toerusting vir die hantering van dokumente en data (CAN/CGSB 2008:3; EN 2006:7-8). Die ASTM-standaard (2014:5) plaas die onus op die kliënt om 'n geskikte vertaaldiensverskaffer te kies deur onder andere die grootte van die projek sowel as enige spesiale vereistes soos spesifieke dokumentformate in ag te neem. Rekenaargesteunde vertaaltegnologie word slegs genoem in CAN/CGSB 131.10 (2008:3), terwyl ISO 17100 (2015:17) 'n lys voorbeelde van vertaaltegnologie bevat en ISO/TS 11669 (2012:32-34) meer inligting oor die gebruik van masjienvertaling verskaf. In hierdie tegnologiese era is dit vir die vertaalkantoor belangrik om te weet watter van hierdie hulpbronne in 'n spesifieke projek aangewend kan word, nie net om die projek meer winsgewend te maak nie, maar veral om vertaalgehalte te verseker.

\section{Slotsom}

Verskille en ooreenkomste tussen die siening van kwaliteit in die vertaalteorie en in die vertaalbedryf is in hierdie artikel uitgewys. Dit is gedoen deur kernstappe vir kwaliteitbestuur in standaarde vir die vertaalbedryf te identifiseer, te beskryf in watter mate hierdie stappe in akademiese vertaalkantore toegepas sou kon word, en raakpunte en verskille met die vertaalteorie te identifiseer. In teenstelling met die preskriptiewe linguistiese vertaalbenaderings met 'n enger fokus op die vertaalproduk, neem funksionalistiese vertaalbenaderings (Holz-Mänttäri 1984; Nord 1991, 1997, 2005; Reiss en Vermeer 1984, 1991; Vermeer 1978) die konteks en doel van die vertaling in ag, sowel as die verskillende rolspelers wat by die produksieproses betrokke is. Hierdie breër siening van vertaling as 'n handeling en ooreenkoms tussen die rolspelers word weerspieël in kwaliteitstandaarde wat spesifiek vir die vertaalbedryf ontwikkel is, soos ISO 17100 (2015) en ASTM F2575 (2014). Akademiese vertaalkantore waar hoërisikovertaling (soos die vertaling van eksamenvraestelle) gedoen word, behoort sover moontlik die kernstappe vir kwaliteitbestuur wat in hierdie standaarde geïdentifiseer word, toe te pas. Die ekonomiese druk op hoëronderriginstellings veroorsaak egter dat akademiese vertaalkantore nie al hierdie kernstappe kan toepas nie, maar ter wille van finansiële volhoubaarheid genoop word om die risiko's en beskikbare hulpbronne teen mekaar op te weeg om die verlangde kwaliteit met so min moontlik hulpbronne te lewer. Die voortbestaan van akademiese vertaalkantore is van kardinale belang aan hoëronderriginstellings waar die taaldiversiteit van personeel en studente erken word.

\section{Bronnelys}

ASTM F2575 Standard guide for quality assurance in translation. 2014. 2de uitgawe. West Conshohocken, PA: ASTM Internasionaal.

Baker, M. en G. Saldanha (reds.). 2009. Routledge encyclopedia of translation studies. 2de uitgawe. Londen: Routledge. 
Bonnet, B. 2006. Quality standards: A sign of the industry's maturity? MultiLingual Junie: 45-48.

CAN/CGSB 131.10 Translation services. 2008. Kanadese Raad vir Algemene Standaarde: Gatineau, Kanada.

Chesterman, A. en E. Wagner. 2002. Can theory help translators? A dialogue between the ivory tower and the wordface. Manchester: St Jerome.

Colina, S. 2008. Translation quality evaluation: Empirical evidence for a functionalist approach. The Translator 14(1): 97-134.

Corpas Pastor, G. 2006. Translation quality standards in Europe: An overview. In E. Miyares Bermúdez en L. Ruiz Miyares (reds.) Linguistics in the twenty first century. Newcastle: Cambridge Scholars Press. pp. 47-57.

Doherty, S., F. Gaspari, F. Groves, J. van Genabith, L. Specia, L. Burchardt, A. Lommel en H. Uszkoreit. 2013. Mapping the industry I: Findings on translation technologies and quality assessment. Aanlyn beskikbaar: http://www.qt21.eu/launchpad/sites/default/files/QTLP_Survey2i.pdf (25 Maart 2016).

Drugan, J. 2013. Quality in professional translation. Assessment and improvement. Londen: Bloomsbury.

EMT Expert Group. 2009. Competences for professional translators, experts in multilingual and multimedia communication. Aanlyn beskikbaar:

http://ec.europa.eu/dgs/translation/programmes/emt/key_documents/emt_competences_translators_en. pdf (30 Augustus 2013).

EN 15038 Translation services - Service requirements. 2006. Europese Komitee vir Standaardisasie: Brussel, België.

Englund Dimitrova, B. 2010. Translation process. In Y. Gambier en L. van Doorslaer (reds.) Handbook of translation studies. Volume 1. Amsterdam: John Benjamins. pp. 406-411.

Göpferich, S. 2009. Towards a model of translation competence and its acquisition: The longitudinal study TransComp. In S. Göpferich, A. Jakobsen en I. Mees (reds.) Behind the mind: Methods, models and results in translation process research. Copenhagen Studies in Language 37. Copenhagen: Samfundslitteratur. pp. 11-37.

Göpferich, S. 2013. Translation competence: Explaining development and stagnation from a dynamic systems perspective. Target 25(1): 61-76.

Göpferich, S., G. Bayer-Hohenwarter, F. Prassl en J. Stadlober. 2011. Exploring translation competence acquisition: Criteria of analysis put to the test. In S. O'Brien (red.) Cognitive explorations of translation. Londen: Continuum. pp. 57-85.

Göpferich, S., A. Jakobsen en I. Mees (reds.). 2008. Looking at eyes: Eye-tracking studies of reading and translation processing. Copenhagen: Samfundslitteratur.

Hansen, G. 2008. The speck in your brother's eye - the beam in your own. Quality management in translation and revision. In G. Hansen, A. Chesterman en H. Gerzymisch-Arbogast (reds.) Efforts and models in interpreting and translation research. Amsterdam: John Benjamins. pp. 255-280.

Holz-Mänttäri, J. 1984. Translatorisches Handeln: Theorie und Methode [Vertaalhandeling: Teorie en metode]. Helsinki: Suomalainen Tiedeakatemia. 
House, J. 1997. Translation quality assessment: A model revisited. Tübingen: Gunter Narr Verlag.

House, J. 2007. Translation criticism: From linguistic description and explanation to social evaluation. In M. Bertuccelli Papi, G. Cappelli en S. Masi (reds.) Lexical complexity: Theoretical assessment and translational perspectives. Pisa: Pisa University Press. pp. 37-52.

Hurtado Albir, A. 2015. The acquisition of translation competence. Competences, tasks, and assessment in translator training. Meta: Translators' Journal 60(2): 256-280.

Ipsen, A. en H. Dam. 2016. Translation revision: Correlating revision procedure and error detection. Hermes: Journal of Language and Communication in Business 55: 143-156.

ISO (Internasionale Standaardiseringsorganisasie). S.j.(a). What is a standard? Aanlyn beskikbaar: http://www.iso.org/iso/home/standards.htm (8 Februarie 2016).

ISO. S.j.(b). About ISO. Aanlyn beskikbaar: http://www.iso.org/iso/home/about.htm (8 Februarie 2016).

ISO. S.j.(c). ISO 9000 - Quality management. Aanlyn beskikbaar:

http://www.iso.org/iso/home/standards/management-standards/iso_9000.htm (6 April 2016).

ISO 17100 Translation services - Requirements for translation services. 2015. Internasionale Standaardiseringsorganisasie: Genève, Switserland.

ISO Quality Services Bpk. 2015. ISO 17100 - The new translation services standard. Aanlyn beskikbaar: http://www.isoqsltd.com/general/iso-17100-new-translation-services-standard/ (25 Maart 2016).

ISO/TS 11669 Translation projects - General guidance. 2012. Internasionale Standaardiseringsorganisasie: Genève, Switserland.

Künzli, A. 2007. Translation revision: A study of the performance of ten professional translators revising a legal text. In Y. Gambier en R. Stolze (reds.) Doubts and directions in translation studies. Amsterdam: John Benjamins. pp. 115-126.

Martin, T. 2007. Managing risks and resources: A down-to-earth view of revision. The Journal of Specialised Translation 8: 57-63. Aanlyn beskikbaar: http://www.jostrans.org/issue08/art_martin.pdf (2 Maart 2011).

Mossop, B. 2014. Revising and editing for translators. 3de uitgawe. Londen en New York: Routledge.

Nord, C. 1991. Scopos, loyalty, and translational conventions. Target 3(1): 91-109.

Nord, C. 1997. Translating as a purposeful activity: Functionalist approaches explained. Manchester: St Jerome.

Nord, C. 2005. Text analysis in translation: Theory, methodology, and didactic application of a model for translation-oriented text analysis. 2de uitgawe. Amsterdam: Rodopi.

Nord, C. 2010. Functionalist approaches. In Y. Gambier en L. van Doorslaer (reds.) Handbook of translation studies. Volume 1. Amsterdam: John Benjamins. pp. 120-128.

Ørsted, J. 2001. Quality and efficiency: Incompatible elements in translation practice? Meta: Translators' Journal 46(2): 438-447. Aanlyn beskikbaar:

http://www.erudit.org/revue/meta/2001/v46/n2/003766ar.pdf (21 Maart 2017). 
PACTE (Process of Acquisition of Translation Competence and Evaluation). 2008. First results of a translation competence experiment: "Knowledge of translation" and "efficacy of the translation process". In J. Kearns (red.) Translator and interpreter training: Issues, methods and debates. Londen: Continuum. pp. 104-126.

PACTE. 2011. Results of the validation of the PACTE translation competence model: Translation project and dynamic translation index. In S. O'Brien (red.) Cognitive explorations of translation. Londen: Continuum. pp. 30-53.

PACTE. 2014. First results of PACTE group's experimental research on translation competence acquisition: The acquisition of declarative knowledge of translation. In R. Muñoz Martín (red.) Minding translation/Con la traducción en mente. Spesiale uitgawe van MonTI: Monografías de traducción e interpretación. San Vincente del Raspeig: Universitat d'Alacant. pp. 85-115.

Petersen, M. 1996. Translation and quality management: Some implications for the theory, practice and teaching of translation. Hermes, Journal of Linguistics 16: 201-220. Aanlyn beskikbaar: http://download2.hermes.asb.dk/archive/download/H16_09.pdf (21 Maart 2017).

Prioux, R. en M. Rochard. 2007. Economie de la révision dans une organisation internationale: Le cas de l'OCDE [Ekonomie van revisie in 'n internasionale organisasie: Die geval van die OECD]. The Journal of Specialised Translation 8: 21-41. Aanlyn beskikbaar:

http://www.jostrans.org/issue08/art_prioux_rochard.php (12 Februarie 2012).

Reiss, K. 1971/2000. Translation criticism: The potentials and limitations. Vertaal deur E. Rhodes. Manchester: St Jerome.

Reiss, K. en H. Vermeer. 1984. Grundlegung einer allgemeinen Translationstheorie [Grondslag vir 'n algemene vertaalteorie]. Tübingen: Niemeyer.

Reiss, K. en H. Vermeer. 1991. Grundlegung einer allgemeinen Translationstheorie [Grondslag vir 'n algemene vertaalteorie]. 2de uitgawe. Tübingen: Niemeyer.

Robert, I., A. Remael en J. Ureel. 2017. Towards a model of translation revision competence. The Interpreter and Translator Trainer 11(1): 1-19.

RSA (Republiek van Suid-Afrika). 2014. Wet op die Suid-Afrikaanse Raad vir Taalpraktisyns (no. 8 van 2014. Aanlyn beskikbaar: https://archive.opengazettes.org.za/archive/ZA/2014/governmentgazette-ZA-vol-587-no-37660-dated-2014-05-19.pdf (6 Mei 2017).

SAVI (Suid-Afrikaanse Vertalersinstituut). 2017. SATI's strategic planning a year on. Muratho 17(1): $5-6$.

Schäffner, C. 2009. Functionalist approaches. In M. Baker en G. Saldanha (reds.) Routledge encyclopedia of translation studies. 2de uitgawe. Londen: Routledge. pp. 115-121.

Schwieter, J. en A. Ferreira (reds.). 2017. The handbook of translation and cognition. Hoboken, NJ: John Wiley and Sons.

Shreve, G. en E. Angelone (reds.). 2010. Translation and cognition. Amsterdam: John Benjamins.

Stejskal, J. 2009. Quality assessment in translation. In M. Forstner, H. Lee-Jahnke en P. Schmitt (reds.) CIUTI-Forum 2008. Enhancing translation quality: Ways, means, methods. Bern: Peter Lang. pp. 291-300. 
US (Universiteit Stellenbosch). 2016. Taalbeleid van die Universiteit Stellenbosch. Aanlyn beskikbaar: http://www.sun.ac.za/english/Documents/Language/Finale\%20Junie\%20Taalbeleid\%20November\%2 02016.pdf (1 Januarie 2017).

US Taalsentrum. 2012. Taaldiens Stylgids. Aanlyn beskikbaar:

http://www0.sun.ac.za/taalsentrum/assets/files/TaaldiensDokumente/stylgids_2013_voorblad.pdf (5 Januarie 2017).

US Taalsentrum. 2014. Style guide of the Language Centre. Aanlyn beskikbaar: http://www0.sun.ac.za/taalsentrum/assets/files/Style\%20Guide\%202014\%20final\%20for\%20web.pdf (5 Januarie 2017).

Van Dyk, T., A. van Rensburg en F. Marais. 2011. Levelling the playing field: An investigation into the translation of academic literacy tests. Tydskrif vir Taalonderrig/Journal for Language Teaching 45(1): 153-169.

Van Rensburg, A. 2012. Die impak van revisie op vertaalde eksamenvraestelle in 'n hoëronderwysomgewing. LitNet Akademies 9(2): 392-412. Aanlyn beskikbaar:

http://litnet.co.za/assets/pdf/4GWvan\%20Rensburg.pdf (21 Maart 2017).

Van Rensburg, A. 2014. Minimum vereistes vir professionele vertalers: Vertaalvermoë volgens die teorie en in die praktyk. LitNet Akademies 11(2): 553-595. Aanlyn beskikbaar: http://litnet.co.za/assets/pdf/joernaaluitgawe_11_2/11_2_Van_Rensburg.pdf (1 Januarie 2017).

Van Rensburg, A. Ter perse. Developing assessment instruments: The effect of a reviser's profile on the quality of the revision product. Aanvaar vir publikasie in G. Koby en I. Lacruz (reds.) "Translator quality - Translation quality: Empirical approaches to assessment and evaluation", Linguistica Antverpiensia, New Series: Themes in Translation Studies 16.

Venuti, L. (red.). 2004. The translation studies reader. 2de uitgawe. Londen: Routledge.

Vermeer, H. 1978. Ein Rahmen für eine allgemeine Translationstheorie ['n Raamwerk vir 'n algemene vertaalteorie]. Lebende Sprachen 23(3): 99-102.

Vermeer, H. 1996. A skopos theory of translation: Some arguments for and against. Heidelberg: TEXTconTEXT. 